\title{
Physiological and biochemical changes in Matricaria chamomilla induced by Pseudomonas fluorescens and water deficit stress
}

\author{
Hamid MOHAMMADI ${ }^{1 *}$, Mohammad ESMAILPOUR ${ }^{2}$, Samaneh GHORBI $^{1}$, Mehrnaz HATAMI $^{3}$
}

Received July 31, 2017; accepted March 07, 2018.

Delo je prispelo 31. julija 2017, sprejeto 07. mareca 2018.

\begin{abstract}
Environmental stresses and rhizosphere microorganisms affect growth parameters and accumulation of active ingredients especially in plants with medicinal properties. The present study examined the effects of chamomile (Matricaria chamomilla L.) seedling inoculation with Pseudomonas fluorescens PF-135 strain on its growth parameters, photosynthetic pigments, proline, malondialdehyde (MDA), and hydrogen peroxide $\left(\mathrm{H}_{2} \mathrm{O}_{2}\right)$ content, and essential oil concentration at both regular watering and water deficit experiments. Based on the obtained results, water deficit stress reduced root dry mass, and flower fresh and dry mass as well. However, amount of $\mathrm{H}_{2} \mathrm{O}_{2}$ and MDA in root and shoot tissues were considerably lower in inoculated plants compared to non-inoculated ones under both normal watering and water deficit regimes. It indicates that lipid peroxidation and production of reactive oxygen species has been diminished in inoculated plants. Also, essential oil content in inoculated plants significantly increased compared with that of noninoculated ones under water deficit stress condition. It can be concluded that $P$. fluorescens $\mathrm{PF}-135$ strain has an outstanding potential to alleviate adverse effects of water deficit on plant growth, and hence can be used as an excellent PGPR in order to boost chamomile productivity especially under water deficit stress condition.
\end{abstract}

Key words: PGPR; chamomile; essential oil; injury indices; water deficit stress

\author{
IZVLEČEK
}

FIZIOLOŠKE IN BIOKEMIČNE SPREMEMBE PRAVE KAMILICE (Matricaria chamomilla L.) VZPODBUJENE Z BAKTERIJO Pseudomonas fluorescens IN POMANKANJEM VODE

Okoljski stresi in mikroorganizmi $\mathrm{v}$ rizosferi vplivajo na rastne parametre in na kopičenje aktivnih snovi, še posebej v rastlinah $\mathrm{z}$ zdravilnimi lastnostmi. V raziskavi so bili preučevani učinki inokulacije sejank kamilice (Matricaria chamomilla L.) s sevom bakterije Pseudomonas fluorescens PF-135 na njene rastne parametre, vsebnost fotosinteznih barvil, prolina, malondialdehida (MDA), vodikovegan peroksida $\left(\mathrm{H}_{2} \mathrm{O}_{2}\right)$ in eteričnih olj v razmerah rednega zalivanja in ob pomanjkanju vode. Rezultati so pokazali, da je pomanjkanje vode zmanjšalo suho maso korenin in svežo ter suho maso cvetov. Količini $\mathrm{H}_{2} \mathrm{O}_{2}$ in MDA v tkivih korenin in poganjkov sta bili manjši pri inokuliranih rastlina $\mathrm{v}$ primerjavi $\mathrm{z}$ neinokuliranimi pri obeh vodnih režimih. To kaže, da je bila peroksidacija lipidov in tvorba reaktivnih zvrsti kisika manjša pri inokuliranih rastlinah. Tudi vsebnost eteričnioh olj se je pri inokuliranih rastlinah značilno povečala $\mathrm{V}$ primerjavi $\mathrm{Z}$ neinokuliranimi $\mathrm{v}$ razmerah pomanjkanja vode. Zaključili bi lahko, da ima sev bakterije $P$. fluorescens PF-135 izjemen potencial za odpravljanje škodljivih učinkov pomanjkanja vode na rast rastlin in bi bil lahko uporabljen kot odlična PGPR snov za povečanje pridelka kamilice, še posebej v razmerah pomanjkanja vode.

Ključne besede: PGPR; kamilica; eterična olja; indeksi poškodovanosti; sušni stres

\section{INTRODUCTION}

Chamomile (Matricaria chamomilla L.) is a wellknown herbaceous annual medicinal plant belonging to Asteraceae family. It is widely used in traditional medicine and pharmaceutical and cosmetic industries around the globe (Frank and Schilcher, 2005). Chamomile possesses antimicrobial and antioxidant properties and significant antiplatelet and anticancer activities (Srivastava et al., 2010; Charousaei et al., 2011; Roby et al., 2013). Flower of chamomile contains essential oil and flavonoids, which contribute to its medicinal properties (Srivastava and Gupta, 2015).

\footnotetext{
1 Faculty of Agriculture, Azarbaijan Shahid Madani University, Tabriz, Iran. *Email Correspondence: hmohammadi@azaruniv.edu

2 Department of Plant Production and Genetic, Faculty of Agriculture, Jahrom University, Jahrom, Iran

3 Department of Medicinal Plants, Faculty of Agriculture and Natural Resources, Arak University, Arak, Iran
} 
Water stress adversely affects physiological aspects of plants (Farooq et al., 2009). One of the inevitable consequences of water deficit is emergence of various reactive oxygen species (ROSs) in different cellular compartments (Cruz de Carvalho, 2008). If amount of ROSs inside the cell exceed the certain threshold, they become extremely deleterious, initiating uncontrolled oxidative cascades that damage photosynthetic pigments, enzymes and other cell constituents (Gill and Tuteja, 2010; Mittler, 2002). ROSs may also attack cellular membrane phospholipids, leading to production of malondialdehyde (MDA). Since MDA is one of the resultants of cellular lipid peroxidation, less amount of MDA production is a sign of more cell membrane integrity. Generally, plants employ various strategies to manage ROSs, including increase in antioxidant activity and production of various compatible organic solutes such as proline (Ashraf and Foolad, 2007).

Plant growth promoting rhizobacterias (PGPRs) are sort of beneficial bacteria predominantly living in the soil around the plant root surface (rhizosphere). These kinds of bacteria stimulate growth and development of the plants via production and exudation of several regulatory chemicals (Ghorbanpour et al., 2015). PGPRs increase plant yield and can improve plant tolerance to abiotic stresses as well, and hence are considered as an excellent alternative for chemical fertilizers which threaten environment and human health (Vessey, 2003). The effects of PGPRs on plant performance are complex. They make many positive morphological and physiological changes in plants (Sánchez-Blanco et al., 2004; Glick et al., 2007 and 1995). For example, PGPRs induce synthesis of osmoprotectants such as proline and help the plants to maintain cell membrane integrity especially under stress conditions. Therefore, PGPRs can alleviate adverse effects of environmental stresses on the plants (Christians et al., 2009; Glick et al., 2007; Chauhan et al., 2015).

Among the PGPRs, Pseudomonas fluorescens (Flügge 1886) Migula, 1895 is a dominant Gram-negative, rodshaped bacterium in the soil that contributes to stimulation of plant growth as well as inhibiting growth of pathogens (Mehrabi et al., 2016). There is little information on physiological responses of chamomile to inoculation with these bacteria especially under water deficit stress condition. Therefore, the main objective of present investigation was to evaluate changes in stress related physiological parameters, biomass and essential oil content of chamomile (Matricaria chamomilla L.) in response to $P$. fluorescens inoculation under both water deficit stress and non-stress conditions.

\section{MATERIALS AND METHODS}

\subsection{Plant Growing condition, Treatments and Sampling}

Chamomile (Matricaria chamomilla L.) seeds were purchased from Research Institute of Forests and Rangelands, Karaj, Iran. Sterilized seeds with $1 \%$ sodium hypochlorite were washed three times with distilled water and put on filter paper (Whatman no. 1) in Petri dishes for initiating seed germination.

In order to identify the best fluorescent pseudomonads strain, 20 PGPR strains (belonging to the fluorescent pseudomonads group) were obtained from Department of Plant Protection, Azarbaijan Shahid Madani University, Tabriz, Iran. A single colony of each PGPR strain transferred to $100-\mathrm{ml}$ flasks containing $25 \mathrm{ml}$ of tryptone soybean broth (TSB) and grown aerobically in the flasks on a rotating shaker $(120 \mathrm{rpm})$ for $72 \mathrm{~h}$ at $28^{\circ} \mathrm{C}$. The bacterial suspension centrifuged $(6000 \mathrm{rpm}$ for $15 \mathrm{~min}$ ) and then washed and diluted in sterile $0.85 \% \mathrm{NaCl}$ (saline solution) to attain a final concentration of $109 \mathrm{CFU} \cdot \mathrm{ml}^{-1}$. The PGPR strains then were evaluated based on their ability to increase chamomile seedling growth index in a sand culture assay (data are not shown). Based on the results of this assay, the Pseudomonas fluorescens-135 (PF-135) was determined as the best pseudomonads strain (Mohammadi et al., 2017). Plant growth promoting activities of this strain are shown in Table 1.

Table 1: Multiple plant growth promoting activities of Pseudomonas fluorescens-135 (PF-135).

\begin{tabular}{ccccccc}
\hline \multirow{2}{*}{$\begin{array}{c}\text { Pseudomonas } \\
\text { strains }\end{array}$} & $\begin{array}{c}\text { P solubility } \\
\left(\mu \mathrm{g} \mathrm{ml}^{-1}\right)\end{array}$ & $\begin{array}{c}\text { Siderophore } \\
\text { production }\end{array}$ & $\begin{array}{c}\text { IAA } \\
\text { production } \\
\left(\mathrm{mg} \mathrm{l}^{-1}\right)\end{array}$ & $\begin{array}{c}\text { ACC } \\
\text { deaminase } \\
\text { activity }\end{array}$ & $\begin{array}{c}\text { PhlD } \\
\text { gene }\end{array}$ & $\begin{array}{c}\text { Ecological site of } \\
\text { strains } \\
\text { isolation } \\
\text { (rhizosphere type) }\end{array}$ \\
\hline PF-135 & 328.35 & 0.42 & 2.46 & 1.02 & active & Wheat (cv. Azar2) \\
\hline
\end{tabular}

PGPR: Plant growth promoting rhizobacteria, P: phosphorus, IAA: Indole-3-acetic acid (without presence of tryptophan), ACC: 1-aminocyclopropane-1-carboxylic acid. 
Part of germinated seeds was inoculated with the inoculums $\left(10^{9}\right.$ CFU.ml $\left.{ }^{-1}\right)$ of the promising selected strain (i.e. P. fluorescens PF-135). Then, all of the seeds (inoculated or non-inoculated) were sown in pots containing sandy loam soil. Pots were placed in greenhouse with $16 \mathrm{~h}$ light period per day and $28 / 18{ }^{\circ} \mathrm{C}$ day/night temperatures. Supplementary light $\left(250 \mu \mathrm{mol} \mathrm{m} \mathrm{m}^{-2} \mathrm{~s}^{-1}\right)$ was provided if necessary.

A factorial experiment in randomized complete block design with three replications was performed. Factors were inoculation (i.e. inoculation with $P$. fluorescens PF-135 strain and non-inoculation) and watering regime (i.e. well-watered and watering up to $50 \%$ of soil field capacity, representing non-stress and water deficit stress treatments, respectively). Water deficit stress treatment exerted on the corresponding pots at the initiation of chamomile flowering stage and continued afterward. However, non-stressed pots were continually irrigated normally through the entire experimental period. Plant samples from each treatment were taken at complete flowering stage and kept at $-70{ }^{\circ} \mathrm{C}$ for measuring physiological parameters. Also, part of samples was shade dried for a week and used for extraction of essential oils. Plant morphological traits including shoot and root dry mass and flower fresh and dry mass were assessed at full flowering stage.

\subsection{Plant Physiological Parameters Assays}

\subsubsection{Plastid pigment measurements}

Fifty milligram of fresh shoots were grounded in $0.5 \mathrm{ml}$ of acetone $(80 \% \mathrm{~V} / \mathrm{V})$ in order to extract photosynthetic pigments (i.e. chlorophyll (Chl.) a, Chl. b and carotenoids). The absorbance of the samples was measured at 645,663 , and $470 \mathrm{~nm}$ in a $\mathrm{T} 80^{+} \mathrm{UV}-\mathrm{Vis}$ spectrophotometer (PG Instrument Ltd., UK). Photosynthetic pigment contents were calculated using the following equations as described by Lichtenthaler and Wellburn (1983):

Chl a $(\mathrm{mg} / \mathrm{g}$ FM $)=11.75 \times \mathrm{A} 663-2.35 \times \mathrm{A} 645$

$\mathrm{Chl} \mathrm{b}(\mathrm{mg} / \mathrm{g} \mathrm{FM})=18.61 \times \mathrm{A} 645-3.96 \times \mathrm{A} 663$

Carotenoids $\left(\mathrm{mg} \mathrm{g}^{-1} \mathrm{FM}\right)=4.69 \times \mathrm{A} 470-0.268 \times(20.2$

$\times \mathrm{A} 645+8.02 \times \mathrm{A} 663)$

\subsection{2 $\mathrm{H}_{2} \mathrm{O}_{2}$ content determination}

In order to determine $\mathrm{H}_{2} \mathrm{O}_{2}$ content in shoot and root of chamomile plants, $0.5 \mathrm{~g}$ fresh tissues were homogenized with $5 \mathrm{ml}$ of $0.1 \% \mathrm{w} / \mathrm{v}$ trichloroacetic acid (TCA) and centrifuged $(12,000 \times \mathrm{g}$ for $15 \mathrm{~min})$. Then supernatant $(0.5 \mathrm{ml})$ was supplemented to $0.5 \mathrm{ml}$ of potassium phosphate $\left(\mathrm{KHPO}_{4}\right)$ buffer $(10 \mathrm{mM}, \mathrm{pH} 7.0)$ and $1 \mathrm{ml}$ of potassium iodide $(1 \mathrm{M})$. The upper phase was aliquoted to read its absorbance at $390 \mathrm{~nm}$. $\mathrm{H}_{2} \mathrm{O}_{2}$ was used for graphing calibration curve in order to calculate $\mathrm{H}_{2} \mathrm{O}_{2}$ concentration (Velikova et al., 2000). The content of $\mathrm{H}_{2} \mathrm{O}_{2}$ was expressed as $\mu \mathrm{mol} \mathrm{g}^{-1}$ FM based on the standard curve.

\subsubsection{Assessment of MDA content}

Shoot and root fresh tissues $(0.5 \mathrm{~g}$ each) were crushed and blended in $5 \mathrm{ml}$ of TCA solution $(0.1 \% \mathrm{w} / \mathrm{v})$ and centrifuged $(12,000 \times \mathrm{g}$ for $15 \mathrm{~min})$. Two milliliters of supernatant was added to $2 \mathrm{ml}$ of TBA $(0.6 \% \mathrm{w} / \mathrm{v})$. The mixture incubated at $95{ }^{\circ} \mathrm{C}$ for $30 \mathrm{~min}$; cooled down on ice and the samples were centrifuged $(4,000 \times \mathrm{g}$ for 20 min). Absorbance of supernatant was measured at $532 \mathrm{~nm}$. The amount of MDA calculated based on Heath and Packer (1968). The MDA content was calculated using a correction factor of $155 \mathrm{mM}^{-1} \mathrm{~cm}^{-1}$ and expressed in terms of nmole $\mathrm{g}^{-1} \mathrm{FM}$.

\subsubsection{Determination of proline content}

In order to determine amount of proline free amino acid content in shoot and root, $0.5 \mathrm{~g}$ of fresh tissues were homogenized with $10 \mathrm{ml}$ of $3 \%$ aqueous sulfosalicylic acid and briefly centrifuged. Two milliliters of the supernatant was blended with acid ninhydrin and glacial acetic acid (two milliliters of each). The mixture in test tube was put in a water bath for $1 \mathrm{~h}$ at $100{ }^{\circ} \mathrm{C}$. The reaction mixture was extracted with toluene (four milliliters). Absorbance of the mixture determined at $520 \mathrm{~nm}$ after being cooled down to room temperature. Standard calibration curve was graphed using appropriate proline concentrations (Bates et al., 1973). Finally, based on the standard curve obtained from different concentrations of proline in terms of $\mu$ mole $g_{-}{ }^{1}$ FM was calculated.

\subsubsection{Determination of essential oil yield}

Plant aerial parts (15 g) were shade-dried for a week. In order to extract their essential oils, the dried samples were hydro-distilled in Clevenger apparatus for 4 hours (Letchamo, 1993). The obtained aqueous essential oil was dehydrated by sodium sulfate, then its value was calculated according to its volume to the dry mass of the plant sample (v/w \%).

\subsection{Statistical Analysis}

The obtained data were subjected to analysis of variance by SAS statistical software. Means were compared by Duncan's Multiple Range Test at 0.01 probability level $(P \leq 0.01)$. 


\section{RESULTS}

\subsection{Plant morphological traits}

Significant differences were observed between treatments in the case of root and shoot dry mass and flower fresh/dry mass ( $\mathrm{p}<0.01$ ) (Table 2). Compared to well-watered condition, all of the morphological traits were reduced significantly under water deficit stress condition (Table 3). Compared to non-inoculated plants, inoculated ones possessed highest amount of foregoing traits under both watering conditions (Table 3).

Table 2: Analysis of variance (ANOVA) for different studied traits. Mean squares are shown for main factors and their interactions

\begin{tabular}{|c|c|c|c|c|c|}
\hline \multirow[b]{2}{*}{ Traits } & \multicolumn{5}{|c|}{ Mean squares for sources of variations } \\
\hline & block & $\begin{array}{c}\text { Factor a } \\
\text { (Inoculation) }\end{array}$ & $\begin{array}{l}\text { Factor b } \\
\text { (Watering } \\
\text { regime) }\end{array}$ & $\begin{array}{l}\text { Interaction } \\
\mathrm{a} \times \mathrm{b}\end{array}$ & Error \\
\hline Root dry mass (g) & $0.00298^{* *}$ & $0.00019^{*}$ & $0.0072^{* * *}$ & $0.01599^{* *}$ & 0.00002 \\
\hline Shoot dry mass (g) & $0.2856^{* *}$ & $0.7793^{* *}$ & $1.6339^{* *}$ & $0.0025^{\mathrm{ns}}$ & 0.0019 \\
\hline Flower fresh mass $(\mathrm{g})$ & $0.3295^{* *}$ & $1.1439^{* *}$ & $2.2995^{* *}$ & $0.0647^{* *}$ & 0.0028 \\
\hline Flower dry mass (g) & $0.0315^{* *}$ & $0.1863^{* *}$ & $0.1938^{* *}$ & $0.0137^{* *}$ & 0.0003 \\
\hline Essential oil yield (v/w) \% & $0.0008^{\mathrm{ns}}$ & $1.235^{* *}$ & $0.261^{* *}$ & $0.126^{* *}$ & 0.0016 \\
\hline Chlorophyll $a$ & $0.0034^{\mathrm{ns}}$ & $0.1145^{* *}$ & $0.228^{* *}$ & $0.0114^{\mathrm{ns}}$ & 0.0026 \\
\hline Chlorophyll $b$ & $0.00124^{\mathrm{ns}}$ & $0.01628^{*}$ & $0.0678^{* *}$ & $0.00002^{\mathrm{ns}}$ & 0.00142 \\
\hline Total chlorophyll & $0.0073^{\mathrm{ns}}$ & $0.2174^{* *}$ & $0.5449^{* *}$ & $0.0104^{\mathrm{ns}}$ & 0.0068 \\
\hline Carotenoids & $0.0015^{\mathrm{ns}}$ & $0.049^{* *}$ & $0.09^{* *}$ & $0.0027^{\mathrm{ns}}$ & 0.0023 \\
\hline Root MDA contents & $0.601^{\mathrm{ns}}$ & $26.883^{* *}$ & $28.296^{* *}$ & $14.434^{* *}$ & 0.566 \\
\hline Shoot MDA contents & $0.081^{\mathrm{ns}}$ & $22.509^{* * *}$ & $35.271^{* *}$ & $15.872^{* *}$ & 0.367 \\
\hline Root $\mathrm{H}_{2} \mathrm{O}_{2}$ contents & $0.005^{\mathrm{ns}}$ & $1.3068^{* *}$ & $2.5595^{* *}$ & $1.0585^{* *}$ & 0.0032 \\
\hline Shoot $\mathrm{H}_{2} \mathrm{O}_{2}$ contents & $0.0022^{*}$ & $1.261^{* *}$ & $2.3039^{* *}$ & $0.7752^{* *}$ & 0.0003 \\
\hline Root proline contents & $212.861^{*}$ & $4170.178^{* *}$ & $36259.641^{* *}$ & $1652.076^{* *}$ & 21.021 \\
\hline Shoot proline contents & $21.923^{\mathrm{ns}}$ & $3078.596^{*}$ & $28419.581^{* *}$ & $5344.461^{* *}$ & 384.557 \\
\hline
\end{tabular}

*: Significant at the 0.05 probability level, **: Significant at the 0.01 probability level, and ${ }^{\mathrm{ns}}$ : Not significant.

Table 3: Mean comparison of morphological traits in non-inoculated and inoculated chamomile plants with PGPR under different watering regimes

\begin{tabular}{|c|c|c|c|c|}
\hline \multirow[b]{2}{*}{ Traits } & \multicolumn{2}{|c|}{ Non-inoculated } & \multicolumn{2}{|c|}{ Inoculated } \\
\hline & Well-watered & $\begin{array}{l}\text { Water deficit } \\
\text { stress }\end{array}$ & Well-watered & $\begin{array}{l}\text { Water deficit } \\
\text { stress }\end{array}$ \\
\hline Root dry mass (g) & $0.308^{\mathrm{c}} \pm 0.04$ & $0.267^{d} \pm 0.02$ & $0.389^{\mathrm{a}} \pm 0.05$ & $0.332^{b} \pm 0.04$ \\
\hline Flower fresh mass (g) & $3.448^{\mathrm{b}} \pm 0.05$ & $2.719^{\mathrm{d}} \pm 0.04$ & $4.212^{\mathrm{a}} \pm 0.06$ & $3.19^{\mathrm{c}} \pm 0.03$ \\
\hline Flower dry mass (g) & $1.016^{\mathrm{b}} \pm 0.04$ & $0.829^{c} \pm 0.03$ & $1.333^{\mathrm{a}} \pm 0.05$ & $1.011^{\mathrm{b}} \pm 0.06$ \\
\hline
\end{tabular}

Values with the same letters in each row are not significantly different at $\mathrm{P}<0.05$. 


\subsection{Plant physiological traits}

The photosynthetic pigments were significantly affected by watering regimes and inoculation factors, and there were not significant interaction among levels of the two factors in the case of these traits (Table 2). As shown in table 4, these traits were decreased in response to water deficit stress treatment. Maximum content of photosynthetic pigments were observed in the inoculated plants (Table 4). In the other hand, amount of $\mathrm{H}_{2} \mathrm{O}_{2}$ in inoculated plants was lower than that of noninoculated plants in both watering conditions.
Significant differences were also observed among different treatments in the case of root and shoot MDA contents (Table 1 and Figure 1). The minimum and maximum amount of MDA in both shoot and root tissues were observed in well-watered inoculated plants and water-stressed non-inoculated plants, respectively (Figure 1). Under water deficit stress condition, proline content of root and shoot were significantly $(\mathrm{P}<0.01)$ augmented in bacterial-inoculated chamomiles (Figure $1)$.

Table 4: Mean comparison of some traits in chamomile plants under water deficit stress conditions

\begin{tabular}{cccccc}
\hline Irrigation & $\begin{array}{c}\text { Shoot dry } \\
\text { mass }(\mathrm{g})\end{array}$ & $\begin{array}{c}\text { Chlorophyll a } \\
\left(\mathrm{mg} \mathrm{g}^{-1} \mathrm{FM}\right)\end{array}$ & $\begin{array}{c}\text { Chlorophyll b } \\
\left(\mathrm{mg} \mathrm{g}^{-1} \mathrm{FM}\right)\end{array}$ & $\begin{array}{c}\text { Total } \\
\text { chlorophyll }\end{array}$ & $\begin{array}{c}\text { Carotenoids } \\
\left(\mathrm{mg} \mathrm{g}^{-1} \mathrm{FM}\right)\end{array}$ \\
\hline $\begin{array}{c}\text { Well-watered } \\
\text { Water deficit stress }\end{array}$ & $2.904^{\mathrm{a}} \pm 0.15$ & $0.629^{\mathrm{a}} \pm 0.04$ & $0.406^{\mathrm{a}} \pm 0.03$ & $1.035^{\mathrm{a}} \pm 0.06$ & $0.583^{\mathrm{a}} \pm 0.03$ \\
& $2.79^{\mathrm{b}} \pm 0.12$ & $0.589^{\mathrm{b}} \pm 0.05$ & $0.368^{\mathrm{b}} \pm 0.04$ & $0.957^{\mathrm{b}} \pm 0.05$ & $0.561^{\mathrm{b}} \pm 0.02$ \\
\hline $\begin{array}{c}\text { Non-inoculated } \\
\text { Inoculated }\end{array}$ & $3.413^{\mathrm{b}} \pm 0.05$ & $0.824^{\mathrm{b}} \pm 0.03$ & $0.48^{\mathrm{b}} \pm 0.02$ & $1.305^{\mathrm{b}} \pm 0.05$ & $0.711^{\mathrm{b}} \pm 0.04$ \\
\hline
\end{tabular}

Values with the same letters in each row are not significantly different at $\mathrm{P}<0.05$. 


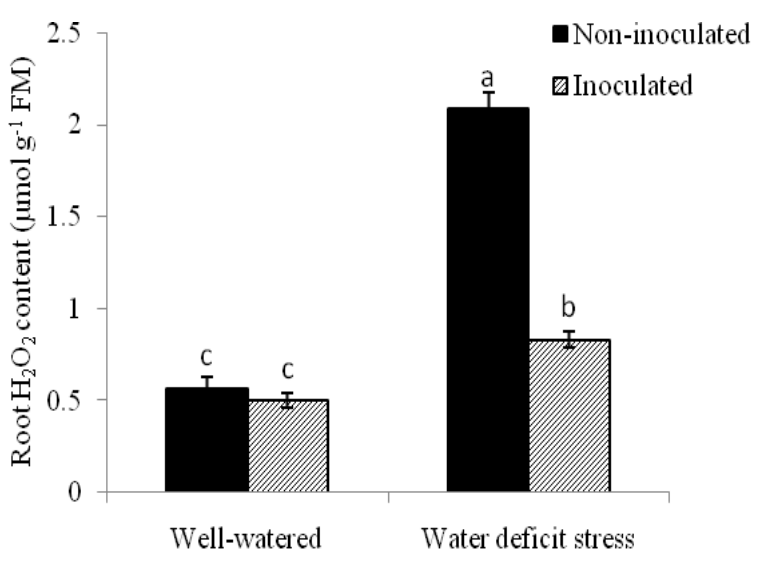

Watering regime

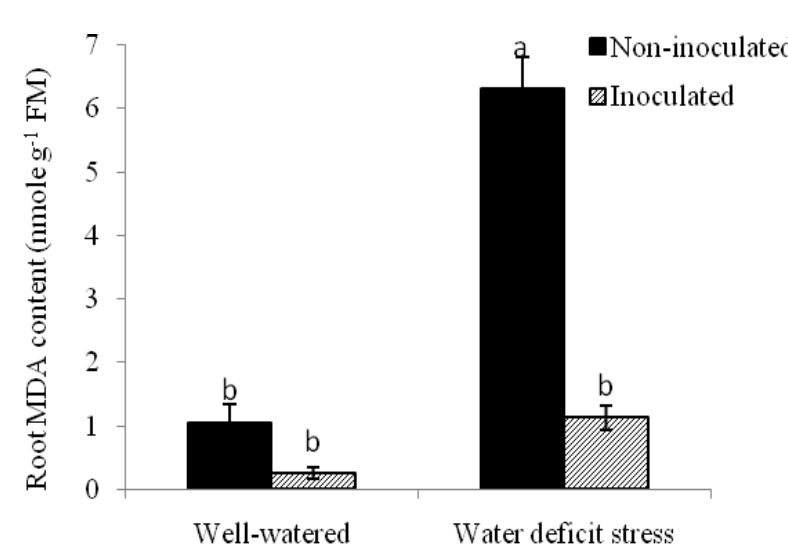

Watering regime

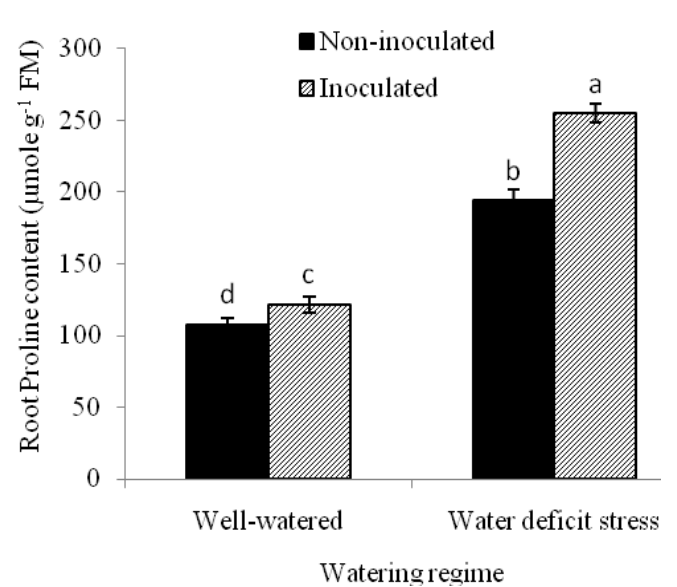

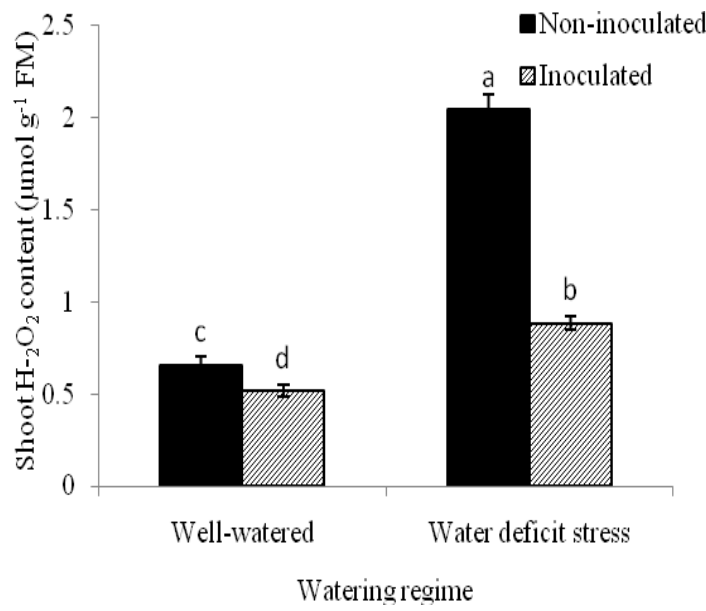

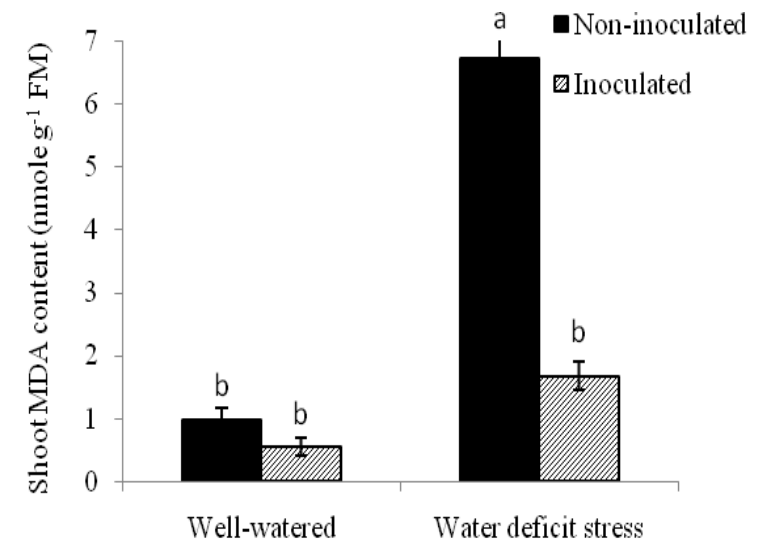

Watering regime

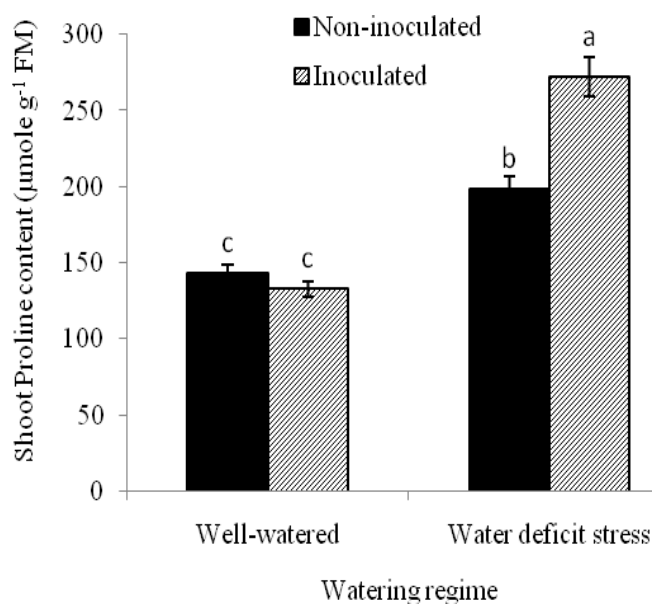

Figure 1: The content of root and shoot $\mathrm{H}_{2} \mathrm{O}_{2}, \mathrm{MDA}$ and proline in non-inoculated and inoculated chamomile plants with PGPR under well-watered and water deficit stress conditions. Columns with the same letters are not significantly different at $\mathrm{P}<0.05$. Vertical bars are $\pm \mathrm{SD}$ of three independent replicates 


\subsection{Essential oils yield}

The results showed that there were considerable variations among treatments in the case of essential oil yield (Table 1). Generally, water-stressed plants had more essential oil than well watered plants regardless of inoculation status. In the other hand, inoculated plants had more essential oil than non-inoculated ones in both watering conditions (Figure 2).

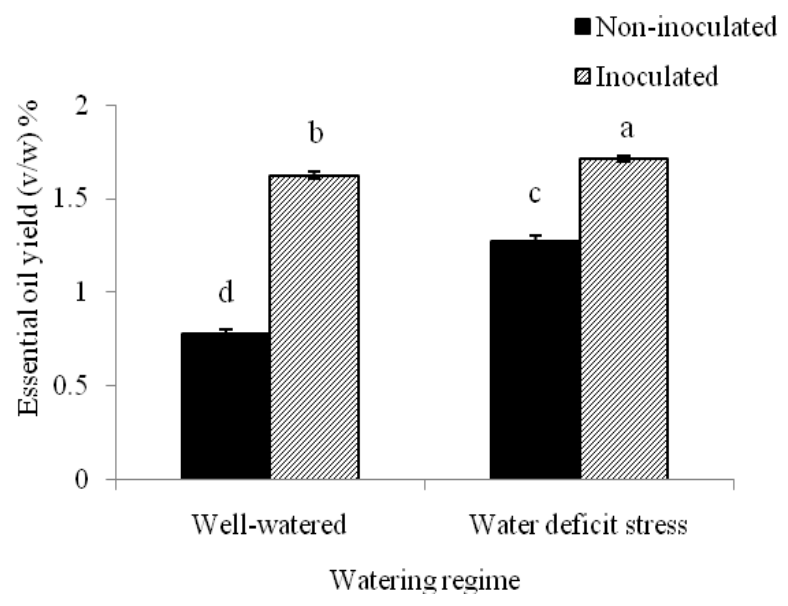

Figure 2: Essential oil yield in non-inoculated and inoculated chamomile plants with PF-135 under well-watered and water deficit stress conditions

\section{DISCUSSIONS}

It is well accepted that PGPRs ameliorate plant growth and productivity by numerous diverse mechanisms. Generally, these mechanisms include: a) producing various plant hormones; b) asymbiotic nitrogen fixation; c) having antagonistic activity against many plant pathogens; d) converting the nutrients into the more accessible forms to be readily absorbed by plant roots, and e) inhibiting synthesis of ethylene precursor in root cells (Yasmin et al., 2007).

In the present study, inoculation of chamomile with $P$. fluorescens PF-135 strain increased flower fresh and dry mass and root dry mass under both water deficit stress and non-stress conditions (Table 3). Mohammadi et al. (2017) reported that inoculation of Satureja hortensis L. with P. fluorescens (PF-135) not only significantly increased the plant biomass and essential oil yields under water deficit stress condition but also improved the activity of antioxidant enzymes and synthesis of proline. Moreover, an investigation on corn inoculated with Pseudomonas spp. under water deficit stress condition also revealed that inoculated plants had higher plant biomass, relative moisture content, proline, sugar, and amino acids compared to that of non-inoculated plants. Besides, inoculated plants had lower electrolytic leakage and higher antioxidant enzymes activity (ascorbate peroxidase, catalase, and glutathione peroxidase) under drought stress condition (Sandhya et al., 2010). These observations showed that inoculated plants compared to non-inoculated ones are less susceptible to stress. It can be attributed to improved plant performance which brought about by $P$. fluorescens inoculation.

Fluorescent pseudomonads are important rhizobacteria which can considerably enhance plant productivity especially under stressful environment. It has been reported that fluorescent pseudomonas are able to synthesis ACC-deaminase enzyme (Saravanakumar and Samiyappan, 2007). This enzyme play a vital role in ameliorating environmental stresses through minimizing ethylene production and stimulating plant root and shoot growth (Glick, 2014; Saleem et al., 2007). These bacteria also inhibit growth of plant pathogenic microorganisms through producing antibiotics. In addition, $P$. fluorescens sustain plant growth via increasing phosphorus solubility, and secreting iron chelating siderophores and indole-3-acetic acid in the soil (Mehrabi et al., 2016).

In this study, leaf MDA and $\mathrm{H}_{2} \mathrm{O}_{2}$ content (as classical markers of oxidative stress) were decreased more than 2-folds in inoculated plants in comparison with noninoculated ones under water deficit stress condition. 
Inoculated plants also synthesized much more amount of proline compared to non-inoculated plants in response to water deficit condition (Figure 1). It has been reported that plants accumulate nitrogen bearing compounds such as amino acids to be able to cope with drought stress (Amunda and Balasubramani, 2011). In addition, proline is considered to be a compatible solute serve to conserve macromolecular structures and cellular membrane integrity as well as tuning osmotic adjustment especially in plants grown under stressful environment (Ashraf and Foolad, 2007; Maggio et al., 2002). Therefore, it can be extrapolated that application of $P$. fluorescens PF-135 strain decreased lipid peroxidation probably through improving plant enzymatic and/or non-enzymatic antioxidant activities.

Plants secondary compounds have variety of ecological functions such as assisting plants to cope better with harsh environments. It has been demonstrated that when plants exposed to water deficit, they produce and accumulate much more secondary compounds compared to normal watering (Selmar and Kleinwachter, 2013). Under water deficit stress condition, plants produce higher amount of terpenes, since photo-assimilates are less allocated to current plant growth demand, resulting in considerable accumulation of essential oils (Turtola et al., 2003). In the other hand, biotic elicitors which are produced and secreted by microorganisms such as bacteria can induce production of plant secondary metabolites. They altogether give details why the plants inoculated with the fluorescent pseudomonads synthesis much more amount of essential oils compared to non-inoculated plants especially under water deficit stress condition (Figure 2). Thus, biological elicitors which are also found in $P$. fluorescens can be used for inducing synthesis of secondary metabolites especially in medicinal plants (Ghorbanpour et al., 2016).

\section{CONCLUSIONS}

Based on the results of the present research, inoculation of chamomile with $P$. fluorescens PF-135 strain significantly boosted essential oil content and plant biomass especially under water deficit condition. Inoculation with $P$. fluorescens PF-135 not only decreased cellular lipid peroxidation but also induced accumulation of proline. Therefore, inoculation of chamomile with $P$. fluorescens alleviated adverse effects of water deficit stress through inducing antioxidant activity, decreasing amount of MDA and $\mathrm{H}_{2} \mathrm{O}_{2}$ as well as increasing proline content. It can be concluded that $P$. fluorescens PF-135 strain is as an excellent PGPR for improving chamomile drought tolerance and boosting its growth and essential oil content especially under water deficit stress condition. Since chemical fertilizers are seriously threatening environment and human health in the globe, therefore PGPRs such as $P$. fluorescens (PF-135 strain) can be considered as one of the outstanding alternative for chemical fertilizers in order to develop sustainable farming especially in dry regions of the world where agricultural ecosystems are fragile.

\section{ACKNOWLEDGEMENTS}

The present investigation was financially supported by the grant number 95/D/897 funded by Deputy of
Research and Technology of Azarbaijan Shahid Madani University, Tabriz, Iran.

\section{REFERENCES}

Ashraf, M., \& Foolad, M.R. (2007). Roles of glycine betaine and proline in improving plant abiotic stress resistance. Environmental and Experimental Botany, 59, 206-216. https://doi.org/10.1016/j.envexpbot.2005.12.006

Bates, L., Waldren, R. \& Teare, I. (1973). Rapid determination of free proline for water-stress studies. Plant and Soil, 39, 205-207. https://doi.org/10.1007/BF00018060

Charousaei, F., Dabirian, A. \& Mojab, F. (2011). Using chamomile solution or a $1 \%$ topical hydrocortisone ointment in the management of peristomal skin lesions in colostomy patients: results of a controlled clinical study. Ostomy-Wound Management, 57, 28-36.

Chauhan, H., Bagyaraj, D.J., Selvakumar, G. \& Sundaram, S.P. (2015). Novel plant growth promoting rhizobacteria-Prospects and potential. Applied Soil Ecology, 95, 38-53. https://doi.org/10.1016/j.apsoil.2015.05.011

Christians, M.J., Gingerich, D.J., Hansen, M., Binder, B.M., Kieber, J.J. \& Vierstra, R.D. (2009). The 
BTB ubiquitin ligases $\mathrm{ETO}_{1}, \mathrm{EOL}_{1}$ and $\mathrm{EOL}_{2}$ act collectively to regulate ethylene biosynthesis in Arabidopsis by controlling type-2 ACC synthase levels. The Plant Journal, 57, 332-345. https://doi.org/10.1111/j.1365-313X.2008.03693.x

Cruz de Carvalho, M.H. (2008). Drought stress and reactive oxygen species: production, scavenging and signaling. Plant Signaling \& Behavior, 3, 156165. https://doi.org/10.4161/psb.3.3.5536

Farooq, M., Wahid, A., Kobayashi, N., Fujita, D. \& Basra, S. (2009). Plant drought stress: effects, mechanisms and management. Agronomy for Sustainable Development, 29, 185-212. https://doi.org/10.1051/agro:2008021

Gill, S.S. \& Tuteja, N. (2010). Reactive oxygen species and antioxidant machinery in abiotic stress tolerance in crop plants. Plant Physiology and Biochemistry, 48, 909-930. https://doi.org/10.1016/j.plaphy.2010.08.016

Glick, B.R. (1995). The enhancement of plant growth by free-living bacteria. Canadian Journal of Microbiology, $\quad 41$, https://doi.org/10.1139/m95-015

Glick, W.H., Miller, C.C. \& Cardinal, L.B. (2007). Making a life in the field of organization science. Journal of Organizational Behavior, 28, 817-835. https://doi.org/10.1002/job.455

Glick, B.R. (2014). Bacteria with ACC deaminase can promote plant growth and help to feed the world. Microbiological Research, 169(1), 30-39. https://doi.org/10.1016/j.micres.2013.09.009

Ghorbanpour, M., Hatami, M., Kariman, K. \& Khavazi, K. (2015). Enhanced Efficiency of Medicinal and Aromatic Plants by PGPRs. In: Plant-GrowthPromoting Rhizobacteria (PGPR) and Medicinal Plants, pp. 43-70. E. Dilfuza, Sh. Smriti, V. Ajit (eds.). Springer International Publishing. Switzerland. https://doi.org/10.1007/978-3-31913401-7_3

Ghorbanpour, M., Hatami, M., Kariman, K. \& Abbaszadeh, P. (2016). Phytochemical variations and enhanced efficiency of antioxidant and antimicrobial ingredients in Salvia officinalis as inoculated with different rhizobacteria. Chemistry \& Biodiversity, 13, 319-330. https://doi.org/10.1002/cbdv.201500082

Heath, R.L. \& Packer, L. (1968). Photoperoxidation in isolated chloroplasts: I. Kinetics and stoichiometry of fatty acid peroxidation. Archives of Biochemistry and Biophysics, 125, 189-198. https://doi.org/10.1016/0003-9861(68)90654-1
Letchamo, W. (1993). Nitrogen application affects yield and content of the active substances in chamomile genotypes. New Crops. Willey. New York, 636639.

Lichtenthaler, H.K., Wellburn, A.R. (1983). Determinations of total carotenoids and chlorophylls $\mathrm{a}$ and $\mathrm{b}$ of leaf extracts in different solvents. Biochemical Society Transactions, 11, 591-592. https://doi.org/10.1042/bst0110591

Maggio, A., Miyazaki, S., Veronese, P., Fujita, T., Ibeas, J.I., Damsz, B., Narasimhan, M.L., Hasegawa, P.M., Joly, R.J. \& Bressan, R.A. (2002). Does proline accumulation play an active role in stress-induced growth reduction? The Plant Journal, 31, 699-712. https://doi.org/10.1046/j.1365-313X.2002.01389.x

Mehrabi, Z., McMillan, V.E., Clark, I.M., Canning, G., Hammond-Kosack, K.E., Preston, G., Hirsch, P.R. \& Mauchline, T.H. (2016). Pseudomonas spp. diversity is negatively associated with suppression of the wheat take-all pathogen. Scientific. Reports, 6, 1-9. https://doi.org/10.1038/srep29905

Mittler, R. (2002). Oxidative stress, antioxidants and stress tolerance. Trends in Plant Science, 7, 405410. https://doi.org/10.1016/S13601385(02)02312-9

Mohammadi, H., Dashi, R., Farzaneh, M., Parviz, L., \& Hashempour, H. (2017). Effects of beneficial root pseudomonas on morphological, physiological, and phytochemical characteristics of Satureja hortensis (Lamiaceae) under water stress. Brazilian Journal of Botany, 40(1), 41-48. https://doi.org/10.1007/s40415-016-0319-2

Roby, M.H.H., Sarhan, M.A., Selim, K.A.H. \& Khalel, K.I. (2013). Antioxidant and antimicrobial activities of essential oil and extracts of fennel (Foeniculum vulgare L.) and chamomile (Matricaria chamomilla L.). Industrial Crops and Products, 44, 437-445. https://doi.org/10.1016/j.indcrop.2012.10.012

Saleem, M., Arshad, M., Hussain, S. \& Bhatti, A.S. (2007). Perspective of plant growth promoting rhizobacteria (PGPR) containing ACC deaminase in stress agriculture. Journal of Industrial Microbiology \& Biotechnology, 34, 635-648. https://doi.org/10.1007/s10295-007-0240-6

Sánchez-Blanco, M.J., Ferrández, T., Morales, M.A., Morte, A. \& Alarcón, J.J. (2004). Variations in water status, gas exchange, and growth in Rosmarinus officinalis plants infected with Glomus deserticola under drought conditions. Journal of Plant Physiology, 161, 675-682. https://doi.org/10.1078/0176-1617-01191 
Sandhya, V. S. K. Z., Ali, S. Z., Grover, M., Reddy, G., \& Venkateswarlu, B. (2010). Effect of plant growth promoting Pseudomonas spp. on compatible solutes, antioxidant status and plant growth of maize under drought stress. Plant Growth Regulation, 62(1), https://doi.org/10.1007/s10725-010-9479-4 21-30.

Saravanakumar, D. \& Samiyappan, R. (2007). ACC deaminase from Pseudomonas fluorescens mediated saline resistance in groundnut (Arachis hypogea) plants. Journal of Applied Microbiology, 102, 1283-1292. https://doi.org/10.1111/j.13652672.2006.03179.x

Selmar, D. \& Kleinwächter, M. (2013). Stress enhances the synthesis of secondary plant products: the impact of stress-related over-reduction on the accumulation of natural products. Plant and Cell Physiology, 54, 817-26. https://doi.org/10.1093/pcp/pct054

Srivastava, J.K., Shankar, E. \& Gupta, S. (2010). Chamomile: A herbal medicine of the past with a bright future (Review). Molecular Medicine Reports, 3, 895-901.

Srivastava, J.K. \& Gupta, S. (2015). Chamomile: A herbal agent for treatment of diseases of the elderly.
In Foods and Dietary Supplements in the Prevention and Treatment of Disease in Older Adults, pp. 171-183. R. R. Watson (ed.). Academic Press, Tokyo, Japan. https://doi.org/10.1016/B9780-12-418680-4.00018-X

Turtola, S., Manninen, A.M., Rikala, R. \& Kainulainen, P. (2003). Drought stress alters the concentration of wood terpenoids in Scots pine and Norway spruce seedlings. Journal of Chemical Ecology, 29, 19811985. https://doi.org/10.1023/A:1025674116183

Velikova, V., Yordanov, I. \& Edreva, A. (2000). Oxidative stress and some antioxidant systems in acid rain-treated bean plants: protective role of exogenous polyamines. Plant Science, 151, 59-66. https://doi.org/10.1016/S0168-9452(99)00197-1

Vessey, J.K. (2003). Plant growth promoting rhizobacteria as biofertilizers. Plant and Soil, 255, 571-586. https://doi.org/10.1023/A:1026037216893

Yasmin, F., Radziah, O., Mohd, S.S. \& Kamaruzaman, S. (2007). Screening for beneficial properties of rhizobacteria isolated from sweetpotato rhizosphere. Biotechnology, 6, 49-52. https://doi.org/10.3923/biotech.2007.49.52 